\title{
Indigenous Epistemologies, Worldviews, and Theories of Power
}

\author{
${ }^{1}$ D. Hickey, ${ }^{2}$ K. Fitzmaurice
}

1. Student, Anishinaabe, Master of Indigenous Relations, Laurentian University

2. Associate Professor, Indigenous Studies, Laurentian University

\begin{abstract}
The current project aims to identify and explore concepts of power from an Indigenous understanding. The topic of power is informed by vast literature that reaches back into the beginnings of western philosophy. The conceptions that result are based on a western worldview that does not incorporate cultural differences. An Indigenous theory of power can be used to inform strategies toward achieving a more equal distribution of power, and encourage successful Indigenous-settler reconciliation. Within the academic setting, Indigenous scholars are developing Indigenous research initiatives aimed at decolonizing methodologies and achieving intellectual self-determination (Smith, 2012, p.120). Utilizing a decolonization framework saturated with reflexivity, Indigenous research methods in conversation with grounded theory will be applied to identify an Indigenous worldview of power. Researcher reflexivity, relationships with community and research-based support systems are requisite to a decolonization research framework (Smith, 1999, p.138). Data collection will occur at M'Chigeeng First Nation and the Chief of that community has been recruited as community partner to this project. Together we aim to answer Indigenous questions to improve Indigenous lives with research based on standards for how we should structure our relationships with each other and with all of creation (Wilson, 2001, p.177). Indigenous research methods combined grounded theory allows the project to bridge worldviews, while allowing for relationships to guide the process. A literature analysis, interviews, sharing circles and review of historical records will be used.
\end{abstract}

Keywords: Power, Indigenous epistemologies, Indigenous methodologies, theories of power.

\section{References}

Smith, L. T. (1999). Decolonizing Methodologies: Research and Indigenous Peoples. New York: Zed Books.

Wilson, S. (2008). Research is Ceremony: Indigenous Research Methods. Halifax: Fernwood Publishing. 